GLOBAL MEDICAL ETHICS

\title{
Benefit sharing: it's time for a definition
}

\section{Schroeder}

J Med Ethics 2007;33:205-209. doi: 10.1136/jme.2006.016790

Benefit sharing has been a recurrent theme in international debates for the past two decades. However, despite its prominence in law, medical ethics and political philosophy, the concept has never been satisfactorily defined. In this conceptual paper, a definition that combines current legal guidelines with input from ethics debates is developed. Philosophers like boxes; protective casings into which they can put concisely-defined concepts. Autonomy is the human capacity for selfdetermination; beneficence denotes the virtue of good deeds, coercion is the intentional threat of harm and so on. What about benefit sharing? Does the concept have a box and are the contents clearly defined? The answer to this question has to be no. The concept of benefit sharing is almost unique in that various disciplines use it regularly without precise definitions. In this article, a definition for benefit sharing is provided, to eliminate unnecessary ambiguity.

\begin{abstract}
Correspondence to: D Schroeder, Centre for Professional Ethics, University of Central Lancashire, Harrington Building, Preston PR 1 2HE, UK; dschroeder@uclan.ac. uk
\end{abstract}

Received 6 April 2006 Revised 14 May 2006 Accepted 15 May 2006

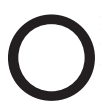

ne of the advantages of moving from mainland Europe to the Anglo-American world is that the Oxford English dictionary (OED) is an accepted tool for philosophical analysis. Yet, benefit sharing has not made an entrance in the OED. Likewise, the largest and most up-to-date bioethics encyclopaedia is empty between "beneficence" and "bias in research". ${ }^{1}$ And the very recent International encyclopaedia of intellectual property treaties has no entry on benefit sharing either. ${ }^{2}$

Let us therefore start from scratch. According to the OED, "benefit" delineates an advantage or a profit gained from something. For example, Jonas enjoys the benefits of being a sports club member. "To share" means to give a portion of something to another. For instance, Janina shared the pie with Jonas. The straightforward linguistic definition for benefit sharing could therefore be that benefit sharing is the action of giving a portion of advantages/profits to others. That was easy enough, although it makes benefit sharing sound like the leisure pursuit of a Sunday afternoon philanthropist. Please note "advantages/profits" was chosen deliberately to capture the notion that benefit sharing relates to monetary and nonmonetary benefits. I take it for granted that access to a genetic resource has been obtained by respecting legal and ethical guidelines. Hence, I shall concentrate on benefit sharing after obtaining access.

\section{INTERNATIONAL LEGAL FACET}

In the legal field, benefit sharing is a technical term used in the context of access to and use of human and non-human genetic resources. Nonhuman genetic resources include plants, animals and microorganisms. The term describes an exchange between those who grant access to a particular resource and those who provide compensation or rewards for its use.

\section{Non-human genetic resources}

The term arose from the Convention on Biological Diversity $^{3}$ (CBD) adopted at the Earth Summit in Rio de Janeiro, Brazil. This global convention has 188 parties and aims to achieve three objectives:

1. the conservation of biological diversity;

2. the sustainable use of its components; and

3. the fair and equitable sharing of benefits from the use of genetic resources.

A short example: the traditional plant knowledge of the Kalahari San people is currently being developed into a potential treatment for obesity by a large European food company. During times of famine, the San people used the appetite-suppressing properties of the so-called Hoodia plant as a food and drink substitute. A benefit-sharing agreement between San representatives and the patent holder, who identified the molecular basis for the appetite suppressant, was signed in $2003 .{ }^{4}$

\section{Human genetic resources}

In 1995, the parties to the CBD agreed to exclude human genetic resources from its scope; "The Conference of the parties reaffirms that human genetic resources are not included in the framework of the Convention" (CBD COP Decision II/ 11). ${ }^{5}$ As a result, no legally binding framework exists to regulate benefit sharing in the context of human resources. The Human Genome Organisation Project ethics committee statement on benefit sharing recommended in 2000 that "all humanity share in, and have access to, the benefits of genetic research". ${ }^{6}$ The 1997 United Nations Educational, Scientific, and Cultural Organisation (Unesco) Universal Declaration on the Human Genome and Human Rights suggested that "benefits from advances in biology, genetics and medicine, concerning the human genome, shall be made available to all." ${ }^{\prime 7}$ The 2005 Unesco Universal Declaration on Bioethics and Human Rights includes a separate article on benefit sharing (Article 15), which demands a sharing of

Abbreviations: $C B D$, Convention on Biological Diversity; $\mathrm{OAU}$, Organisation of African Unity; OED, Oxford English dictionary; Unesco, United Nations Educational, Scientific, and Cultural Organisation; WTO, World Trade

Organisation 
benefits of the results of scientific research, in particular with developing countries. ${ }^{8}$

None of the above international guidelines for non-human or human genetic resources defines benefit sharing. Instead, the parties to the CBD noted in decision VII/19B that relevant national definitions of benefit sharing shall be collated by an ad hoc open-ended working group. The working group published preliminary results in November 2004, ${ }^{9}$ and four existing definitions were identified..$^{10}$ The latest meeting of the working group in February 2006 decided to "postpone consideration of this issue until the negotiation of the international regime on access and benefit-sharing had reached a more advanced stage" (UNEP/CBD/COP/8/6 meeting documents). ${ }^{9}$

Admittedly, with the exception of the UK entry, I find the listed definitions puzzling (which may be due to missing context or inadequate translations). They are either unclear or they are not definitions. To capture the international legal context, the following modification of the linguistic definition therefore seems more appropriate (additions or modifications italicised). Benefit sharing is the action of giving a portion of advantages/profits derived from the use of genetic resources or traditional knowledge to resource providers. This definition is broad enough to encompass human and non-human genetic resources, although benefit sharing for human genetic resources is not an international legal requirement.

In addition to international guidelines and national law, regional associations have formulated voluntary guidelines or model laws. For example, the Organisation of African Unity (OAU); (now African Union) developed a model law to regulate access to and benefit sharing for non-human genetic resources. In contrast with international regulations, the OAU provided a definition of benefit sharing-benefit sharing is the sharing of whatever accrues from the use of biological resources, community knowledge, technologies, innovations or practices. ${ }^{11}$

This definition is a vast improvement on some of the national definitions given earlier. However, it fails in one important respect. It does not specify that two parties have to participate in a legal benefit-sharing process; otherwise the process should be called charitable giving. With whom are the benefits of whatever accrues from the use of biological resources (see below) to be shared? This obvious question remains unanswered in the OAU definition with two implications. Firstly, on the basis of this definition, we could demand benefits even if we were not in any way connected with the used resource. I could demand a share in the benefits derived from using the appetite-suppressant qualities of the Hoodia cactus. This is absurd but best guarded against in a definition. Secondly, the definition seems to imply that all uses of resources warrant benefit sharing. However, it is perfectly plausible and desirable that the providers of a resource should use it themselves. If this were the case, no benefit sharing would be required. So, I shall not amend my previous definition at this stage. The concept of biological resource is much broader than genetic resource. Biological resource includes, for instance, derivatives and biochemical reactions, which are excluded from the genetic resource. Even assuming "biological" can be used as a synonym for "genetic", the definition would still be unhelpful as a generic definition for benefit sharing, because it broadens the scope to include, for instance, practices and innovations, without further specification of how this relates to genetic resources.

\section{ETHICS FACET}

Can ethics add something to the benefit-sharing box that goes beyond the legal contribution? Yes, it can. To step from law to ethics and vice versa normally requires intricate moves in jurisprudence. This is not the place to outline such moves. For the purpose of defining benefit sharing, let us therefore assume a simplified link between ethics and law. Laws reduce individual freedom. To justify the coercion associated, a higher good needs to be invoked. The relevant higher good is typically a normative end-for instance, the prevention of harm. The contribution from ethics to the benefit-sharing box would therefore have to paint the broader picture-namely, the normative justification for benefit sharing and ethical limitations to its application. But please note, this broader picture must accept guidance from law and policy developments to be pertinent to the overall discussion on benefit sharing. Benefit sharing based on a common heritage idea emerged in the 1970s with the following two agreements: (United Nations) Agreement governing the activities of states on the Moon and other celestial bodies (1979) and Convention on the Law of the Sea (1982).

I shall differentiate between non-human and human genetic resources for the following reason: early ethical pronouncements suggest that "the human genome is part of the common heritage of humanity." ${ }^{12} 13$ In contrast, non-human genetic resources lie in the sovereign right of states (Article 3 of the CBD). I shall not assume that ownership issues with regard to genetic resources have been resolved satisfactorily in either discipline, but they are currently viewed differently, warranting two separate definitions.

\begin{tabular}{ll} 
Table 1 National definitions of benefit sharing-Convention on Biological Diversity \\
\hline National definitions & Source \\
\hline Taking part on [sic] benefit(s) of any kind arising from utilisation of genetic resources. & Czech Republic \\
$\begin{array}{l}\text { Monetary advantages sharing deriving or not from exploitation of these genetic } \\
\text { resources between possessors country and users, but also at the level of possessor } \\
\text { country in taking into account local communities and traditional knowledge. }\end{array}$ & Madagascar \\
$\begin{array}{l}\text { Means the sharing of benefits arising from the use, whether commercial or not, of } \\
\text { genetic resources, and may include both monetary and non-monetary returns. }\end{array}$ & UK \\
$\begin{array}{l}\text { It is an obligation that must be fulfilled in all actions related to access to genetic } \\
\text { resources or to traditional knowledge. This obligation is derived from the Convention on } \\
\text { Biological Diversity. This participation must be fair and equitable. To fulfill these } \\
\text { essential requirements, before an authorisation is granted, there must be access to } \\
\text { information, sufficient time for the resource supplier to independently analyse the } \\
\text { information received and definition of control mechanisms regarding the use that will be } \\
\text { given to the elements being accessed. }\end{array}$ & Costa Rica \\
\hline
\end{tabular}




\section{Justification for benefit sharing-non-human genetic resources}

The normative justification for benefit sharing in the context of non-human genetic resources can be taken straight from the CBD. The CBD identified the conservation of biological diversity as "a common concern of humankind" (Articlel5(1)). World leaders meeting at the 2002 World Summit on Sustainable Development in Johannesburg, South Africa, agreed that the destruction of biological diversity would continue unabated unless the custodians of this natural wealth benefit from its conservation. In short, without fair benefit sharing, the conservation and sustainable use of non-human genetic resources will continue to be at risk. In this respect, the justification for benefit sharing according to the CBD relies on a mutually beneficial instrumental approach. In Aristotelian terms, we are dealing with "commutative justice", where each party gives one thing and receives another, with a focus on the equivalence of the exchange. In the case at hand, the exchange takes place between the provision of access for bioprospecting and compensation, be it monetary or non-monetary.

Beyond the requirement for a just exchange, the CBD also delivers an instrumental reason for compliance (beyond staying within the law). The protection of biodiversity is in the selfinterest of humankind. The loss of biodiversity threatens our food supplies, opportunities for recreation and tourism, and sources of wood, medicines and energy. It also interferes with essential ecological functions. ${ }^{14}$ Bearing this in mind, the CBD seems like a real winner: an international, high-profile, legally binding document with a strong Aristotelian justice framework and its own instrumental reason for compliance. But, alas, it lacks strong enforcement mechanisms, as enforcement is devolved to national governments. It is easy to imagine the difficulties of enforcing CBD compliance across borders with local legislation. Also, it does not help that the US is one of the minuscule number of countries not to have signed up to the CBD as a party.

Sustained efforts have been made to supply an indirect enforcement mechanism to the CBD by linking it with the World Trade Organisation's (WTO's) Trade-related Intellectual Property Rights agreement. In a submission to the WTO led by India, it was suggested that a benefit-sharing check list ought to be included in trade-related intellectual property rights to bridge the gap between the two agreements. ${ }^{15}$ This suggestion aroused strong opposition from a group of industrialised countries led by the US. The issue remains unresolved after the recent WTO meeting in Hong $\mathrm{Kong}^{16}$ and is the main hindrance to realising the objectives of the CBD. ${ }^{17}$

Despite the practical difficulties in realising the objectives of the $\mathrm{CBD}$, it is possible to add a contribution from ethics to our definition for non-human resources. "Benefit sharing is the action of giving a portion of advantages/profits derived from the use of non-human genetic resources or traditional knowledge to the resource providers, in order to achieve justice in exchange." In other words, benefit sharing is not an act of charitable giving in the context of non-human genetic resources. If we use resources we do not own, justice demands some form of compensation in exchange.

\section{Justification for benefit sharing - human genetic resources}

Although wide agreement exists regarding the normative justification for benefit sharing in the context of non-human genetic resources, the same cannot be said for human genetic resources. Essentially, four different justification models cover the main possibilities:

1. The outcomes of human genetic research are sufficient benefits for both cooperators and the public at large.
2. Cooperators who cannot benefit directly from genetic research (eg, donors of DNA samples for large-scale studies) qualify for some form of additional benefits, whereas cooperators who can benefit directly (eg, recipients of experimental drugs in pharmacogenetics trials) do not. ${ }^{18}$

3. All cooperators qualify for additional benefits (owing to the risks involved or because their property is being used). ${ }^{19}$

4. Altruism should be the guiding principle for contributors to human genetic research. ${ }^{20}$

A mixture of possibilities (1) and (4) dominates current practice. The problem with both approaches becomes apparent when we add more questions, such as what if the outcomes of genetic research benefit only selective groups? For instance, the population of sub-Saharan Africa accounts for just $\geqslant 10 \%$ of the world's population, but for almost two thirds of people living with HIV or AIDS. If infection and treatment rates continue unabated, $60 \%$ of today's Southern African 15-year-olds will not reach their 60 th birthday. ${ }^{21}$ Genetic research might well provide the breakthrough cure or vaccination against HIV, but the chances that those in most urgent need will have genuine access to it are slim. Add to this that these populations are likely research subjects for research on HIV, ${ }^{22}$ and possibilities (1) and (4) become very suspect indeed. Currently listed on the US National Institute of Health website are various clinical trials on HIV vaccines in Africa, South America and the Caribbean.

Despite this strong potential for exploitation, the two main advisory reports on healthcare research in developing countries have failed to deal with the issue of benefit sharing. The Nuffield Council Report on "The ethics of research related to healthcare in developing countries" set the issue of benefit sharing aside, noting that it will require attention in the future. $^{23}$ The US National Bioethics Advisory Commission's report on "Ethical and policy issues in international research: clinical trials in developing countries" only quoted the Human Genome Organisation ethics committee statement. ${ }^{24}$ Clearly, there is a need to re-evaluate existing frameworks and suggest realistic alternatives. As a first step, I should like to suggest the following definition for benefit sharing in the context of human genetic resources:

Benefit sharing is the action of giving a portion of advantages/profits derived from the use of human genetic resources to the resource providers in order to achieve justice in exchange with particular emphasis on the clear provision of benefits to those who may lack reasonable access to resulting products and services.

This definition emphasises the current imbalance between genetic research activity and the distribution of benefits among those contributing to the research. In this regard, it is a contextual, early 21 st century definition with an in-built ethical imperative. But we need more than one ethical imperative.

When human beings are associated with research, we always need to pause and think of the potential for undue inducement. It is unsurprising that the Unesco Universal Declaration on Bioethics and Human Rights includes two demands on benefit sharing: firstly, that the sharing of benefits occurs in the first place and, secondly, that improper inducements are avoided. ${ }^{8}$

Arguably, DNA research targeted at strong health needs of the donating community is not at risk of creating improper inducement. Firstly, donating a DNA sample (eg, through a tongue swab) has almost no physical risk associated with it. Hence, we cannot be induced to risk our own health for 
financial incentives. Secondly, if we do not take part in the research, new health products for our own health needs may not be developed. Thus, undue inducement is apparently not a problem in the type of research we are discussing. But please note the following quotation from a Kenyan sex worker, who took part in genetic research with the aim of producing a vaccine against HIV. Asked whether she had given consent for DNA samples, she replied: "How can you say no to a doctor? ... They are giving us free medical care. If I say no to them, maybe they will say no to me." 25 Although this is anecdotal evidence, we need to operate on a "precautionary principle" basis when faced with human genetic research and informed consent.

This does not mean, that undue inducement should be used as an argument to defeat efforts to achieve benefit-sharing arrangements in human genetic research. As Thambisetty ${ }^{26}$ reasoned convincingly,

The line between unethical inducement and appropriate benefit sharing is a fine one. The sophistication this calls for should not be an obstacle to the development of appropriate benefit-sharing mechanisms, especially where developing countries are concerned.

I shall therefore conclude by adding a cautionary note to my definition of benefit sharing for human genetic resources.

Benefit sharing is the action of giving a portion of advantages/profits derived from the use of human genetic resources to the resource providers to achieve justice in exchange, with a particular emphasis on the clear provision of benefits to those who may lack reasonable access to resulting healthcare products and services without providing unethical inducements.

To define other elements used in the definition (eg, resource providers or reasonable access) would go beyond the scope of this paper.

\section{BRIEF EPILOGUE FOR PHILOSOPHERS}

Two questions are interesting for philosophers in the context of this study: one about the concept of benefit sharing and the other about the internal structure of the definition.

What kind of concept is benefit sharing? An ethical principle comparable to autonomy or justice? No. Benefit sharing, as defined in this paper, is a tool to achieve commutative justice, ${ }^{27}$ an item on a mental tick list. To be just, we have to give a portion of advantages/profits derived from the use of genetic resources to resource providers. Done!

What is the internal structure of the definition? Using the last definition, we can distinguish three elements:

1. description of a tool;

2. justification for its existence in the form of a fundamental ethical principle; and

3. limited advice for its use.

Strictly speaking, the first part of the definition would have been sufficient to capture the essence of benefit sharing. Benefit sharing is the action of giving a portion of advantages/ profits derived from the use of human genetic resources to the resource providers. Clearly, we are dealing with a tool-that is, a device or action to achieve a particular function or outcome. But what exactly is the desired outcome? The answer to this question is given in part two of the definition-namely, to

'Ruth Macklin and Udo Schuklenk pointed this out to me. achieve justice in exchange. Benefit sharing is a device in the toolbox of justice.

The problem with tools is that they can be used without satisfying fundamental ethical principles, because they are often ethically neutral. Assume we had to include women in benefit-sharing negotiations (the tool) to achieve justice in representation (the ethical principle). We could tick the box by including a woman who is known never to speak in the presence of men, thereby violating the underlying principle. To avoid the misuse of the benefit-sharing tool, a third element was added to the definition-namely, with particular emphasis on the clear provision of benefits to those who may lack reasonable access to resulting healthcare products and services without providing unethical inducements. This last part of the definition is meant as a limited guide to applying the benefitsharing tool at the beginning of the 21 st century.

Finally, one note of caution needs to be added. Tools are flexible and benefit sharing can occur in many guises. By defining benefit sharing as a tool in commutative justice, I do not want to imply that benefits are always best shared in market transactions through individually negotiated agreements. On the contrary, I have argued elsewhere ${ }^{28}$ that an essentially just benefit-sharing model already exists between the medical or pharmaceutical industry and human research subjects in developed countries. We have reasonable access to new healthcare products and services, suitable for local health needs and linked to economic prosperity (eg, jobs). Only where no such benefit sharing exists at society level (eg, among sex workers in the Nairobi slums or Kenyan orphanage ${ }^{29}$ ), could individually negotiated agreements be the best way to avoid exploitation for now.

\section{CONCLUSION}

Benefit sharing has been a recurrent theme in international debates, but the concept has never been satisfactorily defined. By linking linguistic, legal and ethical considerations, this paper has provided separate definitions for the context of human and non-human resources. Further research is needed to clarify ownership issues surrounding genetic resources (common heritage or national or private property); investigate issues of exploitation in human genetic research as opposed to more prominent topics in international research ethics and study concerns about undue inducement in the context of human genetic resources, a hitherto neglected area of research.

\section{ACKNOWLEDGEMENTS}

I thank Rachel Wynberg, Michael Parker, Carolina Lasén Díaz, Armin Schmidt, Peter Herissone-Kelly, Miltos Ladikas and Julie Cook Lucas for comments on an earlier draft.

Competing interests: None.

\section{REFERENCES}

1 Post SG, ed. Encyclopedia of bioethics. Chicago: MacMillan, 2003.

2 Ilardi A, Blakeney M, eds. International encyclopaedia of intellectual property treaties. Oxford: Oxford University Press, 2004.

3 Convention on Biological Diversity Convention text. Convention on Biological Diversity. 5 June 1992. http://www.biodiv.org/convention/articles.asp (accessed 15 Feb 2006).

4 Wynberg R. Rhetoric, realism and benefit sharing. J World Intellectual Property 2004;7:854-76.

5 Decision II/11 access to genetic resources. http://www.biodiv.org/decisions/ default.aspx?m = COP-02\&id =7084\&lg = 0 (accessed 15 Mar 2006).

6 Knoppers BM, et al. Hugo ethics committee statement on benefit sharing. Clin Genet 2000;58:364-6.

7 Unesco. Universal declaration on the human genome and human rights. 1997. http://portal.unesco.org/en/ev.php-URL_ID = 13177\&URL_DO = DO TOPIC\&URL_SECTION $=201 . \mathrm{html}$ (accessed 15 Mar 2006).

8 Unesco. Universal declaration on bioethics and human rights. 2005. http:// portal.unesco.org/shs/en/file_download.php/ 46133elf4691 e4c6e57566763d474a4dBioethicsDeclaration_EN.pdf (accessed 1 Mar 2006). 
9 Convention on Biological Diversity. http://www.biodiv.org/doc/meetings/ cop/cop-08/official/cop-08-06-en.pdf (accessed 16 Mar 2006).

10 Convention on Biological Diversity. Convention on Biological Diversity. 5 June 1992. UNEP/CBD/WG-ABS/3/4, http://www.biodiv.org/doc/meetings/abs/ abswg-03/official/abswg-03-04-en.pdf (accessed 21 Feb 2006).

11 Organisation of African Unity. African model legislation for the protection of the rights of local communities, farmers, and breeders and for the regulation of access to biological resources. 2000. http://www.grain.org/brl_files/oaumodel-law-en.pdf (accessed 1 Mar 2006).

12 United Nations. Agreement governing the activities of states on the Moon and other celestial bodies. 1979. http://www.unoosa.org/oosa/Spacelaw/ moon.html (accessed 10 May 2006).

13 United Nations. Convention on the law of the sea. 1982. http://www.un.org/ $\mathrm{depts} /$ los/convention_agreements/texts/unclos/closindx.htm (accessed 10 May 2006).

14 Secretariat of the Convention on Biological Diversity. Sustaining life on Earth. 2000. http://www.biodiv.org/doc/publications/cbd-sustain-en.pdf /accessed 28 Feb 2006).

15 World Trade Organisation. The relationship between the Trips Agreement and the Convention on Biological Diversity and the protection of traditional knowledge - Submission by Bolivia, Brazil, Cuba, Dominican Republic, Ecuador, India, Peru, Thailand, Venezuela, 2003. http://docsonline.wto.org/ DDFDocuments/ $t / I P / C / W 403 . d o c$ (accessed 1 Mar 2006).

16 SchroederD, Ladikas $M$, Schuklenk U, et al. Sharing the benefits of genetic research. BMJ 2005;331:1351-2

17 World Trade Organisation. The relationship between the TRIPS agreement and the Convention on Biological Diversity, IP/C/W/368/Rev.1. 2006. http:// www.wto.org/english/tratop_e/trips_e/ipcw368_e.pdf (accessed 15 Mar 2006).
18 Williams G, Schroeder D. Human genetic banking and the limits of informed consent. New Genet Soc 2004;23:89-103.

19 Dickenson D. Consent, commodification and benefit sharing in genetic research. Dev World Bioethics 2004;4:109-24.

20 Berg K. The ethics of benefit sharing. Clin Genet 2001;59:240-3.

21 UNAIDS. Report on the global Aids epidemic - executive summary. 2004. http://www.unaids.org/bangkok2004/GAR2004_html/ExecSummary_en/ Execsumm_en.pdf (accessed 1 Mar 2006).

22 Clinical trials. http://aidsinfo.nih.gov/clinical trials/(accessed 10 Mar 2006).

23 Nuffield Council. The ethics of research related to healthcare in developing countries. 2005. http://www.nuffieldbioethics.org/fileLibrary/pdf/ HRRDC_Follow-up_Discussion_Paper001.pdf (accessed 15 Sept 2005).

24 National Bioethics Advisory Commission. Ethical and policy issues in international research: clinical trials in developing countries. 2001. http:// bioethicsprint.bioethics.gov/reports/past_commissions/nbac_international.pdf (accessed 15 Mar 2006).

25 Li N. Out of the armchair: a bioethics student's search for practical knowledge in kenya. J Bioethics Inq 2004;1:20-6.

26 Thambisetty S. Human genome patents and developing countries. Exeter College: University of Oxford, Study Paper 10. Prepared for the Commission on Intellectual Property Rights: 2001: 35. http://www.iprcommission.org/papers/ $\mathrm{pdf}$ /study_papers/10_human_genome_patents.pdf (accessed 15 Mar 2006).

27 Korthals $M$, de Jonge B. Vicissitudes of benefit sharing of crop genetic resources: downstream and upstream. Dev World Bioethics 2006;3:144-57.

28 Schroeder D, Lasén-Díaz C. Sharing the benefits of genetic resources: from biodiversity to human genetics. Dev World Bioethics 2006;3:135-43.

29 Andanda P. A golden chance for medical ethics in Kenya. SciDevNet 15 June 2004. http://www.scidev.net/Opinions/index.cfm?fuseaction $=$ readOpinions\&itemid $=283$ \&language $=1$ (accessed 10 May 2006)

\section{bmjupdates+}

bmjupdates+ is a unique and free alerting service, designed to keep you up to date with the medical literature that is truly important to your practice.

bmiupdates+ will alert you to important new research and will provide you with the best new evidence concerning important advances in health care, tailored to your medical interests and time demands.

\section{Where does the information come from?}

bmjupdates+ applies an expert critical appraisal filter to over 100 top medical journals A panel of over 2000 physicians find the few 'must read' studies for each area of clinical interest

Sign up to receive your tailored email alerts, searching access and more...

www.bmjupdates.com 